\title{
Pimarane Diterpenes and a Sesquiterpene from Salzmmania nitida
}

\author{
MÁRIO G. DE CARVALHO ${ }^{1}$, JOSINETE S. ALVES ${ }^{2}$, EMIDIO V. LEITÃo DA-CUNHA ${ }^{2,3}$, \\ JOSÉ M. BARBOSA-FILHO ${ }^{2}$ and MARCELO S. DA SILVA ${ }^{2}$ \\ ${ }^{1}$ Departamento de Química, ICE, Universidade Federal Rural do Rio de Janeiro, \\ BR 465, Km. 7, 23850-480 Seropédica, RJ, Brasil \\ ${ }^{2}$ Laboratório de Tecnologia Farmacêutica, Universidade Federal da Paraíba, \\ C.P. 5009, 58051-970 João Pessoa, PB, Brasil \\ ${ }^{3}$ Departamento de Farmácia e Biologia, Universidade Estadual da Paraíba, \\ 58100-000 Campina Grande, PB, Brasil
}

Manuscript received on June 3, 2004; accepted for publication on August 27, 2005; presented by FERNANDO GALEMBECK

\begin{abstract}
Two new terpenoids, (+)-3-oxo-thermarol and 11-acetoxyeudesman-4 $\alpha$-methyl-5 $\alpha$-ol along with the (+)thermarol were isolated from the aerial parts of Salzmmania nitida. The structures and unambiguous ${ }^{1} \mathrm{H}$ and ${ }^{13} \mathrm{C}$ chemical shift assignments were established by spectroscopic means, including homo and heteronuclear techniques.
\end{abstract}

Key words: Salzmmania nitida, Rubiaceae, diterpenes, eudesmane.

\section{INTRODUCTION}

The Rubiaceae family has been shown to be one of much interest in phytochemical investigation due to the presence of species produced biologically active compounds such as alkaloids, flavonoids, antraquinones, saponins and triterpenes. Chinchona, Coffea, Psychotria and Rubia species are genera of this family known due to biosynthesize interesting naphthoquinones and alkaloids such as quinine, caffeine, emetine (Bruneton 1995, Evans 1991). Continuing our phytochemical investigation of plants from the northeastern region of Brazil, we recently reported the first study of Salzmmania nitida D.C. (Rubiaceae), describing the structures of triterpenes isolated from this plant (Alves et al. 2000). This species is a monotypic plant and common in the "restinga" (a kind of sand bank cov-

Correspondence to: Dr. Mário Geraldo de Carvalho

E-mail: mgeraldo@ufrrj.br ered with vegetation) of the Northeast. This work describes the isolation and structural determination of two pimarane diterpenes besides $5 \alpha$-hydroxy$4 \alpha$-methyl-11-O-acethyl-eudesmane obtained from Salzmania nitida (Rubiaceae).

\section{MATERIALS AND METHODS}

\section{GENERAL EXPERIMENTAL PROCEDURE}

Mp's are uncorrected. NMR spectra were recorded on Bruker AC-200 ( $\left.{ }^{1} \mathrm{H}: 200 \mathrm{MHz},{ }^{13} \mathrm{C}: 50,3 \mathrm{MHz}\right)$ and AMX $400\left({ }^{1} \mathrm{H}: 400 \mathrm{MHz},{ }^{13} \mathrm{C}: 100 \mathrm{MHz}\right)$ spectrometers using approximately $10-15 \mathrm{mg}$ of sample dissolved in $0,5 \mathrm{ml}$ of $\mathrm{CDCl}_{3}$ in $5 \mathrm{~mm} \mathrm{NMR}$ tubes. Residual $\mathrm{CHCl}_{3}\left(\delta_{H} 7.24\right)$ and ${ }^{13} \mathrm{CDCl}_{3}\left(\delta_{C}\right.$ 77.00) signals were used as references. Homonuclear $2 \mathrm{D}\left({ }^{1} \mathrm{H}-{ }^{1} \mathrm{H}-\mathrm{COSY}\right.$ and NOESY $)$ and heteronuclear $2 \mathrm{D}\left\{{ }^{1} \mathrm{H}_{-}{ }^{13} \mathrm{C}-\mathrm{COSY}-{ }^{n} \mathrm{~J}_{\mathrm{CH}}\right.$ [n=1, HMQC (modulated with $\mathrm{J}_{C H} 130 \mathrm{~Hz}$ ); and $\mathrm{n}=2$ and 3, $\mathrm{HMBC}$ (modulated with $\mathrm{J}_{C H}=9.0 \mathrm{~Hz}$ )] \} spectra were ob- 
tained with standard pulse sequences. FT-IR spectra were recorded using $\mathrm{KBr}$ disks or $\mathrm{NaCl}$ film on a Perkin-Elmer 1600 spectrometer. Mass spectra were obtained using a VG Auto Spec-300 spectrometer. Chromatography was performed using Aldrich silica gel with a suitable granulation for column and preparative TLC. The visualization of spots was done by UV (254 and $366 \mathrm{~nm}$ ) and exposure to iodine vapor.

\section{Plant Material}

Salzmania nitida D.C. (Rubiaceae) was collected in January 1998 in the surroundings of Santa Rita, State of Paraíba, Brazil, and identified by botanist Dr. Maria de Fátima Agra of the Universidade Federal da Paraíba. A Voucher specimen (Agra 2986) is deposited at the Herbarium Prof. Lauro Pires Xavier (JPB), Universidade Federal da Paraíba.

\section{ISOLATION OF CONSTITUENTS}

The dried and ground aerial parts of S. nitida $(3.40 \mathrm{Kg})$ were extracted in a Soxhlet apparatus with $95 \%$ EtOH. The solvent was removed under vacuum to yield a residue $(180.0 \mathrm{~g})$. This residue was dissolved in $\mathrm{MeOH}$-water(9:1) and subjected to partition with $\mathrm{CHCl}_{3}$ and AcOEt. The residue from the AcOEt fraction $(80.3 \mathrm{~g}$ ) was submitted to a C.C. on silica gel using hexane- $\mathrm{CHCl}_{3}(1: 1)$ as eluent. 76 fractions of $50 \mathrm{~mL}$ each were obtained. Fractions 10-30 and 35-55 yielded $\mathbf{1}(0.10 \mathrm{~g})$, and 2 (0.15 g), respectively, after recrystallization from methanol. Fractions 57-76 were submitted to preparative TLC using hexane:AcOEt $(8: 2)$ to yield the sesquiterpene $3(0.010 \mathrm{~g}$, oil).

(+)-8 $\beta$, 19-dihydroxy-3-oxopimar-15 $\beta$-ene, (+)-3oxo-thermarol (1): M.P. $158{ }^{\circ} \mathrm{C},[\alpha]_{D}=+22.60$ $\left(\mathrm{CHCl}_{3}, \mathrm{c} 0.045\right) .{ }^{1} \mathrm{H}$ and ${ }^{13} \mathrm{C}$ NMR data in Table I.

(+)-8 $\beta$, 19-dihydroxy-pimar-15 $\beta$-ene, (+)-therma$\operatorname{rol}(2)$ : M.P. $148^{\circ} \mathrm{C},[\alpha]_{D}=+8.28\left(\mathrm{CHCl}_{3}, \mathrm{c} 0.052\right)$. ${ }^{1} \mathrm{H}$ and ${ }^{13} \mathrm{C}$ NMR data in Table I.

11-acetoxyeudesman- $4 \alpha$-methyl-5 $\alpha$-ol (3): oil; $\delta_{H}$ $\left(\mathrm{CDCl}_{3}, 500 \mathrm{MHz}\right): 2.2(\mathrm{H}-7, \mathrm{~m}), 1.93(\mathrm{H}-4, \mathrm{H}-1$, m), $1.70(\mathrm{H}-2,6,9, \mathrm{~m}), 1,45(\mathrm{H}-2,3,8, \mathrm{~m}), 1.30(\mathrm{H}-$ 1, 3, 9, m), 1.2 ( $\mathrm{H}-6,8, \mathrm{~m}), 1.95$ (s, $\left.\underline{\mathrm{H}}_{3} \mathrm{CCO}\right), 1.42$ and 1.49 (3H, s, H-12 and 13), $0.84(3 \mathrm{H}, \mathrm{s}, \mathrm{H}-14)$, $0.77(3 \mathrm{H}, \mathrm{d}, 7.0 \mathrm{~Hz}, \mathrm{H}-15) ; \delta_{C}\left(\mathrm{CDCl}_{3}, 125 \mathrm{MHz}\right)$ : 170.5 ( $\left.\mathrm{H}_{3} \mathrm{CCO}\right), 85.2$ (C-11), 73.2 (C-5), 41.1 (C10), 39.4 (C-7), 36.5 (C-9), 32.9 (C-4), 32.0 (C-1), 30.0 (C-6), 29.7 (C-3), 23.4 and 23.2 (C-12 and C13), 22.9 (C-2), 22.4 (C-8), 22.1 ( $\left.\mathrm{H}_{3} \underline{\mathrm{CCO}}\right), 15.2$ (C-14), 15.9 (C-15).

\section{RESULTS AND DISCUSSION}

The analysis of ${ }^{13} \mathrm{C}$ NMR [HBBD and DEPT $(\theta$ : 135 and $\left.90^{\circ}\right)$ ] spectra of $\mathbf{1}$ allowed to identify three methyl, nine methylene, three methyne and five quaternary carbons. The IR spectra of this compound showed bands at $v_{\max } 1715 \mathrm{~cm}^{-1}\left(v_{C=O}\right), 3470$ $\mathrm{cm}^{-1}\left(v_{O H}\right)$ and 3080, 1630, 975 and $910 \mathrm{~cm}^{-1}$ characteristic of a vinyl group. These observations together with a peak at $\mathrm{m} / \mathrm{z}=320\left(\mathrm{M}^{+\cdot}\right)$ in the mass spectrum are in agreement with the molecular formula $\mathrm{C}_{20} \mathrm{H}_{32} \mathrm{O}_{3}$ for 1 . These data are in accordance with an oxo-pimarane diterpene. The ${ }^{1} \mathrm{H}$ NMR spectrum shows singlets at $\delta_{H} 0.92,0.98$ and 1.28 for three methyl groups, two signals at $\delta_{H} 3.45(d$, $11.0 \mathrm{~Hz}, 1 \mathrm{H})$ and $4.05(d, 11.0 \mathrm{~Hz}, 1 \mathrm{H})$ for a hydroxymethylene group and three double doublets at $\delta_{H} 5.13(9.0 \mathrm{~Hz}$ and $2.0 \mathrm{~Hz}, 1 \mathrm{H}), 5.19(16.0 \mathrm{~Hz}$ and $2.0 \mathrm{~Hz}, 1 \mathrm{H})$ and $5.98(16.0 \mathrm{~Hz}, 9.0 \mathrm{~Hz}, 1 \mathrm{H})$ of the identified vinyl group. These groups were also confirmed by cross-peaks in the $2 \mathrm{D}\left({ }^{1} \mathrm{H}_{-}{ }^{13} \mathrm{C}\right.$ COSY, ${ }^{1} \mathrm{~J}_{\mathrm{CH}}$ ) NMR spectrum between those signals and carbon-13 chemical shifts at 16.5, 22.3, 32.5 $\left(\mathrm{CH}_{3}\right), 66.0\left(\mathrm{CH}_{2}\right), 112.8\left(\mathrm{CH}_{2}\right)$ and $147.9(\mathrm{CH})$ relative to connections for methyl groups, hydroxymethylene and vinyl hydrogen, respectively. The HMBC analysis showed ${ }^{2,3} \mathrm{~J}_{C H}$ cross-peak correlation as described in Table I. The NOE observed between $\mathrm{H}_{3} \mathrm{C}-20$, H-1 (eq) and $\mathrm{H}_{2} \mathrm{C}-19$ in ${ }^{1} \mathrm{H}^{-}{ }^{1} \mathrm{H}-$ NOESY experiment, along with the considerable shielding effect on C-18 (22.3) and deshielding on C-4 (51.1), were used to confirm the presence of a carbonyl at C-3 of ring A. The location of the hydroxyl group at C-8 was confirmed by the chemical shift at $72.0 \mathrm{ppm}$ besides the signals of long-range 
TABLE I

${ }^{1} \mathrm{H}$ and ${ }^{13} \mathrm{C}$ NMR data of (+)-3-oxo-thermarol (1) and (+)-thermarol (2) using 1D and $2 \mathrm{D}\left[{ }^{1} \mathbf{J}_{C H},{ }^{1} \mathbf{H}-{ }^{13} \mathrm{C}-\mathrm{COSY}\right.$ (HMQC) and $\left.{ }^{2,3} \mathbf{J}_{C H},(\mathrm{HMBC})\right]$.

\begin{tabular}{|c|c|c|c|c|c|c|}
\hline \multirow{2}{*}{$\mathrm{C}$} & \multicolumn{3}{|c|}{1} & \multicolumn{3}{|c|}{2} \\
\hline & $\delta_{C}$ & $\delta_{H}$ (mult., J Hz) & $2,3 \mathrm{~J}_{C H}$ & $\delta_{C}$ & $\delta_{H}$ & $2,3 \mathrm{~J}_{C H}$ \\
\hline 1 & 38.0 & $\begin{array}{c}1.95(\mathrm{ddd}, 4.5 ; 8.5 \\
14.0 ; \mathrm{H}-\alpha) ; 1.50(\mathrm{~m}, \mathrm{H}-\beta)\end{array}$ & $\mathrm{C}-2 ; 5 ; 10 ; 20$ & 39.7 & $0.85(\mathrm{~m}, \mathrm{H} \beta) ; 1.70(\mathrm{~m}, \mathrm{H} \beta)$ & $\mathrm{C}-2 ; 3 ; 10$ \\
\hline 2 & 34.5 & $\begin{array}{c}2.45(\mathrm{dt}, 8.5 ; 14.0 ; \mathrm{H} \alpha) \\
2.57(\mathrm{ddd}, 4.5 ; 8.5 ; 14.0, \mathrm{H} \beta)\end{array}$ & C- $3 ; 10$ & 18.3 & $1.45-1.55(\mathrm{~m}, 2 \mathrm{H})$ & C- $3 ; 10$ \\
\hline 3 & 220.9 & - & - & 35.8 & $0.92(\mathrm{H} \alpha \mathrm{p} ; 1.80(\mathrm{H} \beta)$ & $\mathrm{C}-2 ; 4 ; 5$ \\
\hline 4 & 51.1 & - & - & 38.9 & - & \\
\hline 5 & 56.8 & 1.25 & C-4;6;18,19 & 57.4 & $1.02(\mathrm{~m})$ & $\mathrm{C}-4 ; 7$ \\
\hline 6 & 18.3 & $1.40-1.65(2 \mathrm{H}-6)$ & $\mathrm{C}-7 ; 8$ & 18.3 & $1.78(\mathrm{H} \alpha) ; 1.22(\mathrm{H} \beta)$ & $\mathrm{C}-5 ; 7 ; 8 ; 10$ \\
\hline 7 & 41.5 & $1.78(\mathrm{H} \alpha) ; 1.22(\mathrm{H} \beta)$ & C-6;9 & 41.6 & $1.45-1.5(2 \mathrm{H})$ & C-9;8 \\
\hline 8 & 72.0 & - & - & 72.7 & - & \\
\hline 9 & 55.1 & 0.95 & C-10;12 & 56.6 & $0.88(\mathrm{dd}, 9.0,3.5)$ & C-10;12 \\
\hline 10 & 36.6 & - & - & 37.4 & - & \\
\hline 11 & 18.6 & $1.46-1.60(2 \mathrm{H}-11)$ & C-9;12;13 & 18.7 & $1.50-1.70(2 \mathrm{H})$ & C-9;13 \\
\hline 12 & 36.3 & $2.03(\mathrm{H} \beta) ; 1.25(\mathrm{H} \alpha)$ & C-11, 13,$14 ; 15$ & 36.2 & $\begin{array}{c}1.21(\mathrm{H} \alpha) ; 2.00(\mathrm{ddd} \\
10.7,6.0,2.9, \mathrm{H} \beta)\end{array}$ & C- $13 ; 15$ \\
\hline 13 & 36.8 & - & - & 36.6 & - & - \\
\hline 14 & 53.0 & $\begin{array}{c}1.26(\mathrm{H} \alpha) ; 1.68 \\
(\mathrm{dd}, 2.0 ; 14.0, \mathrm{H} \beta)\end{array}$ & C-8;12;13;15 & 53.6 & $1.24(\mathrm{H} \alpha) 1.65(\mathrm{dd}, \mathrm{H} \beta)$ & C-13 \\
\hline 15 & 147.4 & $5.98(\mathrm{dd}, 9.0 ; 16.0)$ & C-12;16 & 147.4 & $5.97(\mathrm{dd}, 17.0,11.0)$ & C-12;16 \\
\hline 16 & 112.8 & $\begin{array}{l}5.13(\mathrm{dd}, 2.0 ; 9.0) \\
5.19(\mathrm{dd}, 2.0 ; 16.0)\end{array}$ & C-13;15 & 112.2 & $\begin{array}{l}5.08(\mathrm{dd}, 11.0,1.2) \\
5.13(\mathrm{dd}, 17.0,1.2)\end{array}$ & C-13;15 \\
\hline 17 & 32.5 & $0.92(\mathrm{~s})$ & C-12;13;14;15 & 32.5 & $0.91(\mathrm{~s})$ & C-13;14 \\
\hline 18 & 22.3 & $1.28(\mathrm{~s})$ & $\mathrm{C}-4 ; 5 ; 19$ & 27.2 & $0.91(\mathrm{~s})$ & $\mathrm{C}-3 ; 4 ; 5 ; 19$ \\
\hline 19 & 66.0 & $3.45(\mathrm{~d}, 11.0) ; 4.05(\mathrm{~d}, 11.0)$ & $\mathrm{C}-3 ; 4 ; 5$ & 66.5 & $3.48(\mathrm{~d}, 11.0) 3.08(\mathrm{~d}, 11.0)$ & $\mathrm{C}-3 ; 4$ \\
\hline 20 & 16.5 & $0.98(\mathrm{~s})$ & C-1;5;9;10 & 16.3 & $0.97(\mathrm{~s})$ & C- $1 ; 5 ; 9 ; 10$ \\
\hline
\end{tabular}


coupling with $\mathrm{H}-6, \mathrm{H}-9$ and $2 \mathrm{H}-14$ in the HMBC experiment. Additional signals showing correlation between $3 \mathrm{H}-20$ and $\mathrm{C}-1, \mathrm{C}-5$ and $\mathrm{C}-9,3 \mathrm{H}-17$ with C-12, C-14 and C-15 together with comparison of (-)-thermarol ${ }^{13} \mathrm{C}$ NMR chemical shifts (Matsuo et al. 1976, Ramos et al. 1984) allowed to assign hydrogen and carbon chemical shifts as shown in Table I. The peaks in the mass spectrum of $\mathbf{1}$ have the same $m / z$ values described in the literature for a thermarol derivative (Takaishi et al. 1997). The difference between the $\mathrm{C}-17$ chemical shift in $1\left(\delta_{\mathrm{CH} 3} 32.5\right)$ and that described in the literature $\left(\delta_{C H 3} 24.3\right)$ for $8 \beta$,19-dihydroxy-3-oxopimar- $15 \alpha$ ene (Takaishi et al. 1997) along with the NOE cross peak between $\mathrm{H}-17$ and $\mathrm{H}-14 \alpha$ in the ${ }^{1} \mathrm{H}-{ }^{1} \mathrm{H}-$ NOESY spectrum led us to established an equatorial position for the $\mathrm{C}-17$ methyl group, such as in the representation for (-)-thermarol (Matsuo et al. 1976). Finally, the $[\alpha]_{D}=+22.60\left(\mathrm{CHCl}_{3}, \mathrm{c} 0.045\right)$ allowed to define the structure of $\mathbf{1}$ as (+)-8 $\beta, 19$ dihydroxy-3-oxopimar-15 $\beta$-ene represented for the new diterpene named (+)-3-oxo-thermarol (Fig. 1).

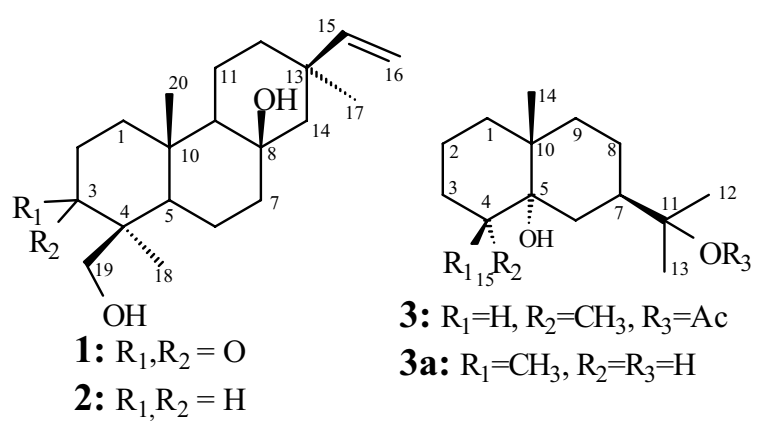

Fig. 1 - Compounds isolated from Salzmmania nitida.

Spectral analysis for 2 led us to identify 20 carbon signals including three methyl, ten methylene, three methyne and four quaternary carbons including two oxigenated carbons $\left(\mathrm{H}_{2} \mathrm{C}-\mathrm{O}\right.$ and $\left.\mathrm{C}-\mathrm{O}\right)$. The molecular formula of $2, \mathrm{C}_{20} \mathrm{H}_{34} \mathrm{O}_{2}$, was compatible with $\mathrm{M}^{+} .306$ observed in the mass spectrum. The ${ }^{13} \mathrm{C}$ NMR spectra data besides the peaks observed in the mass spectrum of $\mathbf{2}$ were identical to those of (-)-thermarol (Matsuo et al. 1976, Ramos et al. 1984). The cross peaks of NOE between $\mathrm{H}-$
9/H-12, H-1/H-20, H-12/H-9, H-17, H-14/H-17, H$19\left(\delta_{H} 3.48\right) / \mathrm{H}-1, \mathrm{H}-20$ and $\mathrm{H}-17 / \mathrm{H}-14 \alpha, \mathrm{H}-15$ observed in the NOESY spectra along with information from homonuclear ${ }^{1} \mathrm{Hx}{ }^{1} \mathrm{H}-\mathrm{COSY}$ were used to confirm the structure for $\mathbf{2}$. Furthermore, this analysis allowed us to make the first detailed assignment of all hydrogen chemical shifts of thermarol, Table I. The optical rotation of $2,[\alpha]_{D}=+8.28$ $\left(\mathrm{CHCl}_{3}, \mathrm{c} 0.052\right)$, has the same sign of (+)-thermarol prepared by reduction of $8 \beta$-Hydroxypimar-15-en19-oic acid, isolated from Taxodium mucronatum (Ramos et al. 1984) (Fig. 1). So, the optical rotation permitted to identify $\mathbf{2}$ as being the natural enantiomer compound (+)-thermarol.

The acetyl derivative of eudesmanediol 3 was identified by IR and NMR spectral analysis besides comparison with data for 5,11-dihydroxy-eudesmane and 11-Acetoxyeudesman-4-ol isolated from Cryptomeria japonica (Su et al. 1995) and from Ursinia species (Jakupovic et al. 1992). The HMQC and $\mathrm{HMBC}$ experiments were useful to assign the carbon and hydrogen chemical shift of $\mathbf{3}$ (see experimental). The analysis of carbon-13 chemical shifts confirmed the location of the tertiary hydroxyl and the acetyl groups in the carbon with chemical shifts at $\delta 73.5(\mathrm{C}-5)$ and 85,2 (C-11), respectively, together with comparison with values for 3a described in literature (Su et al. 1995). The shielding $\gamma$-effect of an axial HO-5 on C-15 $\left(\delta_{C H 3} 15.9, \Delta \delta=\right.$ $6.6 \mathrm{ppm})$ and on $\mathrm{C}-7\left(\delta_{C H} 39.4, \Delta \delta=5.8 \mathrm{ppm}\right)$ besides the expected deshielding effect on C-10 $\left(\delta_{C}\right.$ 41.1, $\Delta \delta=3.5 \mathrm{ppm}$ ) were used to justify the $\alpha$ orientation for $\mathrm{HO}-5$ and $\mathrm{H}_{3} \mathrm{C}-15$. The chemical shift of C-11 $\left(\delta_{C} 85.2\right)$ and of 12/13 methyl groups $\left(\delta_{C H 3} 23.4 / 23.2\right)$ are in agreement with an acetoxy group $\left(\delta_{C=O} 170.5\right.$ and $\left.\delta_{C H 3} 22.1\right)$ at $C-11$. On the basis of these data, the new sesquiterpene (3) was identified as 11-acetoxyeudesman- $4 \alpha$-methyl-5 $\alpha$-ol (Fig. 1).

\section{ACKNOWLEDGMENTS}

The authors are grateful to Conselho Nacional de Desenvolvimento Científico e Tecnológico (CNPq), Coordenação de Aperfeiçoamento de Pessoal de 
Nível Superior (CAPES), Financiadora de Estudos e Projetos (FINEP) and Fundação Carlos Chagas Filho de Amparo à Pesquisa do Estado do Rio de Janeiro (FAPERJ) for grants and fellowships. We also thank Dra. M. de F. Agra (Universidade Federal da Paraíba, João Pessoa, Brasil) for botanical identification and Prof. Alexander I. Gray (Phytochemistry Research Laboratories, Department of Pharmaceutical Sciences, University of Strathclyde, Glasgow, UK) for recording the $400 \mathrm{MHz}$ NMR spectra (Bruker AMX 400).

\section{RESUMO}

O estudo fitoquímico de Salzmmania nitida D.C. (Rubiaceae) conduziu ao isolamento e identificação de dois novos terpenoides, (+)-3-oxo-thermarol e 11-acetoxi4alfa-metil-5alfa-eudesmanol além do (+)-termarol. As estruturas foram estabelecidas com base na análise de espectros de IV, Massas e RMN de ${ }^{1} \mathrm{H} \mathrm{e}{ }^{13} \mathrm{C}$ (1D e 2D).

Palavras-chave: Salzmmania nitida, Rubiaceae, diterpenos, eudesmano.

\section{REFERENCES}

Alves JS, Castro JCM DE, Freire MO, DACunha EVL, BARbosa-Filho JM AND Silva MS DA. 2000. Complete Assignment of the ${ }^{1} \mathrm{H}$ and ${ }^{13}$ C NMR Spectra of four Triterpenes of the Ursane, Artane, Lupane and Fridelane groups. Magn Reson Chem 38: 201-206.
Bruneton J. 1995. Pharmacognosy, Phytochemistry, Medicinal Plants, $2^{\text {nd }}$ ed., Lavoisier, Adover, p. 330887.

EVAns WC. 1991. Farmacognosia, $13^{\mathrm{a}}$ ed. - Interamericana, M. Graw Hill, p. 224-229.

JAKUPOVIC J, GANZER U, PRITSCHOW P, LEHMANN L, Bohlmann F And KIng RM. 1992. Sesquiterpene Lactones and other Constituents from Ursinia species. Phytochemistry 31: 863-880.

Matsuo A, Uto S, Nakayama N, Hayashi S, YAMASAKi K, KASAi R And TANAKA O. 1976. (-)-Thermarol, A New Ent-pimarane-Class Diterpene Diol From Jungermannia thermarum (Liverwort). Tetrahedron Lett 2: 2451-2454.

RAmos AR, EscAmilia EM, CALDERÓN J AND RoDRÍGUES B. 1984. 8?-hydroxypimar-15-en-19-oic acid from Taxodium mucronatum. Phytochemistry 23: 1329-1330.

Su W, FAng J And Cheng Y. 1995. Sesquiterpenes from Leaves of Cryptomeria japonica. Phytochemistry 39: 603-607.

Takaishi Y, Miyagi K, Kawazoe K, NaKano K, Li K AND DuAn H. 1997. Terpenoids From Tripterygium wilfordii Var. Regelii. Phytochemistry 45: 975-978. 